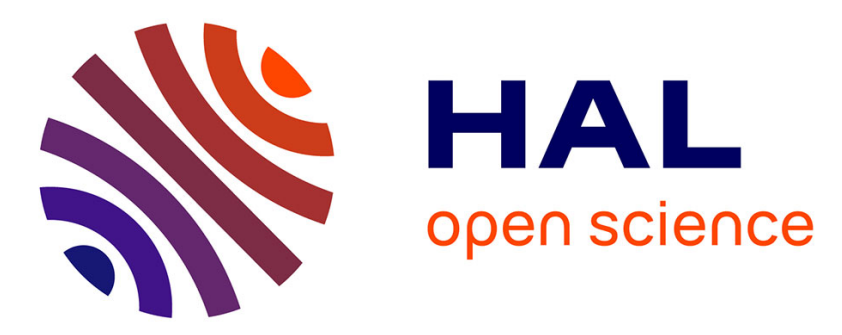

\title{
The "authoritarian culture" in historical perspective: a comparative study between the mafiosi police in Rio de Janeiro and Buenos Aires
}

Luciana Araujo de Paula

\section{- To cite this version: \\ Luciana Araujo de Paula. The "authoritarian culture" in historical perspective: a comparative study between the mafiosi police in Rio de Janeiro and Buenos Aires. 26th World Congress of Philosophy of Law and Social Philosophy of the International Association for Philosophy of Law and Social Philosophy, Aug 2013, Belo Horizonte, Brazil. halshs-00920626}

\section{HAL Id: halshs-00920626 \\ https://shs.hal.science/halshs-00920626}

Submitted on 23 Dec 2013

HAL is a multi-disciplinary open access archive for the deposit and dissemination of scientific research documents, whether they are published or not. The documents may come from teaching and research institutions in France or abroad, or from public or private research centers.
L'archive ouverte pluridisciplinaire HAL, est destinée au dépôt et à la diffusion de documents scientifiques de niveau recherche, publiés ou non, émanant des établissements d'enseignement et de recherche français ou étrangers, des laboratoires publics ou privés. 


\title{
The "authoritarian culture" in a historical perspective: comparative study between the mafiosi police in Rio de Janeiro and Buenos Aires
}

\author{
Luciana Araújo de Paula \\ Doctorante Contractuelle en Science-Politique (CREDA) \\ Institut des Hautes Etudes de l'Amérique latine - Sorbonne Nouvelle/Paris III
}

\begin{abstract}
During the past decade we observe a growing optimism on the Latin American continent. However, it is also the continent where we see the highest rate of homicides and a political corruption increasingly embedded in "organized crime" from the state and in particular, from the members of its security institutions. We refer to new "mafiosi phenomena" who question the belief that Latin America "organized crime" is always linked to "drug traffickers". These new "mafiosi phenomena" are formed in the heart of the state through an "authoritarian culture" firmly rooted in the political and security institutions in Latin America. The evolution of this "authoritarian culture" has followed a common denominator powered by a dual mechanism: individuals require more security against a rising crime, while the state responds advantage repression. We find in the history of the Latin American countries 'standardization' of the repressive behavior of the state in the name of democracy, while strengthening its authoritarian tendencies. Nowadays the emergence of a kind of "police mafiosi" that imposes tax and the "illegal protection" to the poor and relies on the cooperation of politicians eager to vote is nothing other than the perverse result of this process. This "snowball" is it due to the structural weakness of the Latin - American counties? To what extent this paradox is it intrinsic to the process of democratization of Latin American institutions in a transnational context? To what degree this "authoritarian culture" was the springboard for the consolidation of the phenomena of more and more complex within the state apparatus? To address this issue we will do, at first, a comparative study, observing how the phenomenon of "police mafiosi" has established itself in Brazil through the case of "Milicias" in Rio de Janeiro, then Argentina, through the example of the "Policia Maldita" in Buenos Aires.
\end{abstract}




\section{1) Avant-propos}

During the last decade we see a climate of increasing optimism on the economic level of the Latin American continent. However, it is also the continent where we find a very high rate of homicide as well as political corruption more and more linked to the crime from the state in particular, members of its security institutions. I refers to new "mafia phenomena" groups composed of police officers who have developed and consolidated in this atmosphere of economic and "democratic" euphoria. How to understand this paradox?

These new "mafia phenomenon" appeared and gradually rooted in the heart of the state through an "authoritarian culture" well anchored in the political and security institutions. In my doctoral thesis I analyze the structure of the "authoritarian culture" present in the security institutions in Rio de Janeiro and Buenos Aires. I understand by "authoritarian culture" that Paulo Sérgio Pinheiro called a "socially implanted authoritarianism." This means that "certain behaviors and authoritarian values are not affected by the political transitions and institutional change. These behaviors are historical legs, constantly reactivated by the characteristics of social interaction. "

This presentation is part of the fieldwork for my thesis where I analyze some paradigmatic examples of historic joint triptych policy / politics / crime in both Latin American contexts. To understand the phenomenon of "mafiosi police" itself it is necessary to consider other forms of criminal operation of the police who are not necessarily mafia.

Then, how authoritarian culture is present in the practice of security institutions in Rio de Janeiro and Buenos Aires?

To answer this problem I decided to develop an overview of the functioning of the criminal police and separate it into three major groups: 1) "police corruption", 2) "death squads" and, finally, 3) "mafiosi police".

The "mafiosi police" is the one which best articulates this triad (police / politics / crime) on a "territory" and a specific "population". However, it is very important to note that this division does not refer to a "logical evolution of crime", that is to say, from 1 to 3 . These three forms of operation are organized in accordance with the characteristics of each historical political context / social /. Thus, even if they have different modes of action, they often identify with each other because they are from the same institution security: the police.

For example, if the "mafiosi police" uses some features of the "death squads", it can not be mistaken as to the latter. Moreover, there are "territories" or even historical and political contexts that lend themselves to some form of action and not to others. "Police corruption" Brazil is a common mode of operation in certain "territories" of the southern area of the city of Rio de Janeiro usually controlled by factions of drug trafficking. In Argentina, the "death squads" that had a strong nationalist tendencies have spread in specific historical and political contexts: "Ligua Patriótica Argentina" in the '20s and the "Triple A" in the 70s in the third Peron government.

I adopt the binomial "city / territory" in order to better understand the control of certain physical spaces by criminal groups in both countries. The notion of "territory" refers to the idea of a microcosm that includes rules and forms of social organization that differ from those of the city. 
"Territories" are characterized mainly by constant intersection between formal / informal, legal / illegal which promotes the development of these areas groups.

The "Police mafia" itself feeds such blurred distinctions between the formal / legal - they are members of official security institutions and therefore have a duty to protect - and informal / illegal - they take advantage of the lack of distinction on the "territory" to develop their mafiosi activities, for exemple, selling protection, the sale of water, electricity, control of alternative transportation, vehicle theft, prostitution, extortion, among others.

In Rio de Janeiro I will analyze 1) "police corruption" through the model of the "arrego" or "mineira", 2) "death squads" through the model of "the Escuderia Le Coqc" et finally, 3)" mafiosi police" through the model of the "milicias".

In Buenos Aires, I will analyze 1) "police corruption" through the model of "Jaurias de perros" («pack of dogs»); 2) "death squads" through the model of the 'triple A' e finally, the «mafiosi police" through the model of "porongos".

\section{2) Police corruption}

\section{1) Rio de Janeiro}

The fact that the police "negotiating" with organized crime is called "arrego" or "mineira". This practice has been very widespread in 90s. The members of the State Security allow criminal groups, including drug traffickers, develop their illegal activities on a "territory" given (usually in a "point of sale" called "boca de fumo") for a percentage on the profits generated by these sales. Insofar as that trading is profitable for the policy it ensures the smooth running of this "business" and therefore "peace" of "territory". However, if the dealers do not pay the "arrego" the agreement is broken and the police reprises his role and combat it.

\section{2) Buenos Aires}

The model of "Jaurias de perros" has materialized during the mandate of Security Minister Leon Arslanian (2004-2007) that ended the pyramidal system of command within the bonaerense police. This has been positive because it overthrew the entrepreneurial character and hierarchically organized illegal police activities. However, it has also made possible the formation of different autonomous bands of police (called "Jaurias de perros") who disputed the management of illegal activities in the province of Buenos Aires in an uncontrolled manner and extremely violent.

\section{3) Death squads}

\section{1) Rio de Janeiro}

The model of "Escuderie le Cocq" refers to a criminal association formed by the police in Rio de Janeiro to promote the summary execution of suspected individuals bandits. It was founded in 1965 and acts in the 70s, 80s and early 90s. The "Scuderie Le Cocq" was formed to avenge the death of Milton Le Cocq, famous detective and member of the personal guard of Getúlio Vargas. This group was led by the "Twelve gold men" chosen by Luis França, Secretary of Public Security 
of Rio de Janeiro, to "clean" the city of «bandits». This group has been very active during the Brazilian dictatorship and it solicited its services and used his clandestine methods persecution and torture has against the common bandits to combat resistant left of regime.

\section{2) Buenos Aires}

The model "Triple A" refers to the "anticommunist argentine alliance", a death squad of extreme right founded by José López Rega, Argentine Minister of Social Affairs in the third Peronist government from 1973 to 1975 . Lopez Rega was head of the Ministry of Social Welfare, which funds were diverted to finance the organization and armament of this group to fight leftist (early actions were primarily directed towards the left wing of Peronism). After the coup of 1976, the Triple A was taken over by the army and more concretely by SIDE ("Secretary of State Information"). The "Proceso de Reorganización Nacional" has been responsible for the dissolution of the Triple A since "terrorism" became a state policy and actions of the Triple A (now called "Comando Libertadores de América") become institutionalized by the army itself.

\section{4) Mafiosi Police}

\section{1) Rio de Janeiro:}

The model of the "milicia" refers to the "Police Mineira" formed in the late 1970s in the community of Rio das Pedras, region of Jacarepagua in Rio de Janeiro, after a humiliation afflicted by drug traffickers to a resident of the community. Than, this resident formed a group with other residents to establish their own righteousness, expel traffickers and protect the population. The first informations on the "Police Mineira" were ambiguous: they were referring firstly to the presence of coercion, threats and extortion, and secondly to restore order positively perceived by the population. However, certain abusive attitudes have generated discontent among the local population. Due to this the agents of Public Security (polices, firefighters, soldiers...), residents of the community, decided to intervene and arrest the leaders of the "Police Mineira." These agents have replaced the previous group and have expanded their operations in the community, forming the embryo of what the press began to call the "milicia". This model of "territory" control by members of the police claiming the "protection" of the local population through the "sale security" was adopted in neighboring communities forming the bastion of "Milicia" or "blue commando" (due to the color of the uniforms of the Military Police in Rio de Janeiro which has produced the majority of these groups) in the western part of the metropolitan area of the city, especially during the government of the clan Garotinho (Anthony Rosinha and from 99 to 2007).

\section{2) Buenos Aires}

The model of "porongas" (thinking head of a criminal gang, also used in prisions Argentina to refer to the chief prisoner. Makes also echo of manhood as associated to the male sexual organ) has materialized during the Government of the Province of Buenos Aires by Eduardo Duhalde (1991-1999). At this time the triad Police / politics / crime in the metropolitan area of Buenos Aires has become systematic and the term "maldita policia" was born. This system is pyramidal, hierarchical, organic and is characterized by illegal financing ("black box") of each police department in the metropolitan area. Thus, the functions are very organized and defined : the antidrug department is responsible for the management of drug trafficking; the department to combat flight is responsible for the management of flights; the anti-kidnapping department is responsible 
for management kidnapping and extortion ...This model is reinforced by the policies of "mano dura" because they allow the police play with the feeling of insecurity among the population : when they want to promote a political ally they are placed in the street and protect the population, but when it prevents them from developing their illegal activities, they "liberan zonas" for the bandits allies (this strategy has been widely used for removing of leftist activists under the dictatorship: the police "liberava zonas", that is to say, did not intervene in a "territory" determined by the army allowing the death squads execute the "dirty work"). In the 90s, the "mafiosi police" was also used to demonstrate its dissatisfaction with the government through "political messages" for example, several Israeli cemeteries profanations took place in retaliation for investigations against police accused of involvement in the attack against AMIA.

\section{5) Concluding}

At this point of my research I can forward the following differentiation between "mafiosi police" in Rio de Janeiro and Buenos Aires:

In Rio de Janeiro, "police mafia" consists of officers whose purpose is to control the "territory" the local population in order to extortion, saying the fight against crime, particularly against trafficking drugs. Here we see a close relationship "police mafia" / "territory" / locals. They are those who "protect" at the same time that taking advantage the local population of these territories.

In Buenos Aires, the "police mafia" took place the very heart of the police force with the objective of funding the "slush fund" for each department: for example, those who fight against crime on a "territory" are determined also those who manage, which articulate the same crime and redistribute gains. Here we see a close relationship "police mafia" / "territory" / crime management. They are those who "protect" at the same time take advantage of that crime management of these territories.

\section{6) Bibliography}

CHAMPEYRACHE, Clotilde, Sociétés du Crime : um tour du monde des máfias, Paris : CNRS éditions, 2007.

DABÈNE, O., GEISSER, V., MASSARDIER, G., CAMAU, M., Autoritarismes démocratiques et démocraties autoritaires au XXIe siècle : convergences Nord-Sud mélanges offerts à Michel Camau, Paris : la Découverte, 2008.

DELMAS-MARTY, Mireille, Libertés et surêté dans un monde dangereux, Paris : Seuil, 2010.

FAORO, Raymundo. Os Donos do Poder. Formação do patronato político brasileiro, Porto Alegre: Globo, 2000.

FREIDENRBERG, Flavia, La tentación populista : una vía al poder en América Latina, Madrid : Editorial Síntesis, 2007. 
FREGOSI, Renée, Parcours transnationaux de la démocratie : Transition, consolidation, déstabilisation, Bruxelles : P.I.E. Peter Lang, 2011.

GAUCHET, M. La democratie contre elle meme, Gallimard, Paris, 2002.

GAUCHET, M. La démocratie d'une crise à l'autre, Cécile Defaut, Paris, 2007.

HINTON, Mercedes. The state on the streets: police and politics in Argentina and Brazil, 2006.

LEAL, Vitor Nunes, Coronelismo, enxada e voto : o muncípio e o regime representativo no Brasil, São Paulo : Companhia das Letras, 2012.

O’DONNELL, Guillermo. (1999). "Polyarchies and the (Un)rule of law in Latin America: a partial conclusion” in MÉNDEZ, Juan E., O’DONNELL, Guilhermo, PINHEIRO, Paulo Sérgio (eds) The (Un) Rule of Law \& the Underprivileged in Latin America. Indiana. University of Notre Dame Press.

O’DONNELL, Guillermo, Schmitter, Philippe C., Whitehead, Laurence (dir.), Transitions from Authoritarian Rule: Latin America, Baltimore, Md.: The Johns Hopkins University Press, 1986.

PADOVANI, Marcelle. La Sicile comme métaphore, 2003.

POPPER, K., La societé ouverte et ses ennemies, Paris, Seuil, 1979.

ROUQUIÉ, Alain, À l'ombre des dictatures : la démocratie en Amérique latine, Paris : A. Michel, 2010 .

SAIN, Marcelo, Política, Policia y Delito : La red Bonaerense, Buenos Aires : Capital Intelectual, 2004.

TELLES, Vera. A cidade nas fronteiras do legal e ilegal. Belo Horizonte: Argvmentvm, 2010.

VALLESPIR, Alejandra, La policia que supimos conseguir, Buenos Aires : Planeta, 2002. 